\title{
OPTIKAI REZGÉSVIZSGÁLATOK
}

\author{
Lénárt József \\ tanársegéd, Miskolci Egyetem, Szerszámgépészeti és Mechatronikai Intézet, \\ Robert Bosch Mechatronikai Intézeti Tanszék \\ 3515 Miskolc, Miskolc-Egyetemváros, e-mail: lenart.jozsef@uni-miskolc.hu
}

\begin{abstract}
Absztrakt
A cikk az optikai elven müködö rezgésmérési lehetöségeket ismerteti, különös tekintettel a kutatásom témáját adó vonal CCD szenzor alapú megoldásra. Bemutatom az alkalmazott mérési módszereket, azok elönyeit, hátrányait, majd az általam alkalmazott módszert, a megtervezett és elkészitett kísérleti berendezést, annak legutóbbi fejlesztési lépéseit. A méröeszköz legutóbbi fejlesztési lépései elsősorban a kommunikációs alrendszert érintették, melynek segitségével a mért adatok vezeték nélküli hálózaton keresztül a mérés folyamán nyomon követhetök.
\end{abstract}

Kulcsszavak: rezgésmérés, FPGA, CCD

\section{Abstract}

This article describes the optical vibration measurement methods, with particular reference to the line CCD sensor based solution of my research. I present the applicable measurement methods, their advantages and disadvantages, and the experimental equipment designed, and the latest development steps. Recent developments of the instrument have primarily concerned the communication subsystem, whereby the measured data can be tracked over wireless network during the measurement.

Keywords: vibration measurement, FPGA, CCD

\section{Bevezetés}

A rezgésmérés a gépészeti gyakorlatban egy rendkívül fontos terület, akár a karbantartás, hibakeresés, vagy gyártásfelügyelet területén alkalmazzák. A rezgésmérés alapvetően három paraméter egyikének mérésével valósulhat meg:

- gyorsulás,

- sebesség,

- elmozdulás.

A hagyományos rezgésmérési megoldások leginkább a karbantartás és hibakeresés során alkalmazhatók jól, mivel a mérőfejet valahogyan rögzíteni kell a mérendő alkatrészre. Ezen mérési módszerek leggyakrabban rezgésgyorsulást mérnek, melyet integrálva megkapható a rezgéssebesség, kétszer integrálva pedig az elmozdulás. A legelterjedtebb mérőátalakítók piezoelektromos elven mérnek, a testre ható gyorsulás erőhatást hoz létre, ez az erőhatás egy piezoelektromos mérőcellát terhel, amely ennek hatására arányos feszültségjelet ad. Ez az arányos jel megfelelő erősítés és kondícionálás után feldolgozható. A piezoelektromos mérőfejek mellett elterjedőben vannak az ún. MEMS (Micro ElectroMechanical Sensor) típusú érzékelők is, amelyek kisebbek, könnyebbek, olcsóbbak a piezo szenzoroknál. A mérés elve leggyakrabban kapacitív, kimenetükön általában arányos feszültségjel jelenik meg. Léteznek piezorezisztív elven müködő MEMS szenzorok is, melyeket leginkább nagy gyorsulások mérésére alkalmazzák. A MEMS szenzorok felépítésükből adódóan (1. ábra) kisebb tö- 
megüek piezo társaikhoz képest, ami gyakran nagy előnyt jelent, főleg, ha kisebb tömegü alkatrész méréséről van szó.

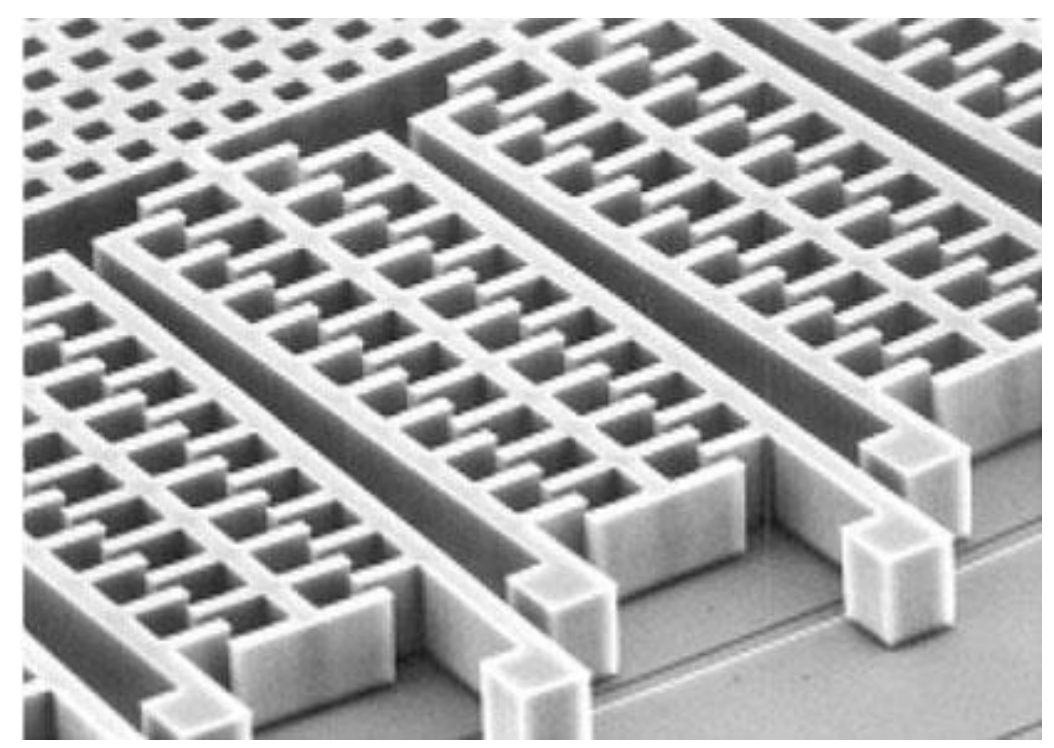

1. ábra. MEMS gyorsulásmérö felépitése [1]

\section{Optikai mérési módszerek}

Egyes esetekben a hagyományos rezgésmérési módszerek alkalmazása nehézkes, vagy lehetetlen, ilyen esetek lehetnek például, ha:

- nagy amplitúdójú (akár több mm), kis frekvenciájú (néhány száz Hz) rezgést kell mérni, ilyen esetekben a piezoelektromos gyorsulásmérök általában rosszul teljesítenek,

- nehezen hozzáférhető géprészek mérése; előfordulhat, hogy a mérőfej hely hiányában nem rögzíthető megfelelően,

- kis tömegú alkatrész mérése esetén a mérőfej relatív nagy tömege túlzottan befolyásolhatja a mérés eredményét.

Ilyen esetekben alkalmazhatók az általában optikai mérési elven müködő érintkezésmentes mérési módszerek. Ezek a módszerek folyamatos távolság-, vagy elmozdulásmérésen alapulnak. Ilyen mérési módszerek:

- LDV: Lézer Doppler Vibrométer,

- háromszögeléses elmozdulásmérö,

- lézer interferométer,

- vonalkamera.

A doppler vibrométer és az interferométer nagyon nagy felbontású és nagy pontosságú mérést tesz lehetővé, viszont nagyon drága és érzékeny berendezések szükségesek hozzá. Kutatásom célkitűzése pont ezzel ellentétes: olyan mérőeszköz tervezése, amely viszonylag olcsó, kisméretü, így akár hoszszabb távú gépfelügyelet céljából egy gép munkaterében is elhelyezhetö.

A háromszögeléses elven müködő elmozdulásmérő ilyen szempontból megfelelöbb, egyrészt jóval olcsóbb eszköz, másrészt kevésbé érzékeny a környezetére. Felépítése és müködésének elve a 2. ábrán látható. 


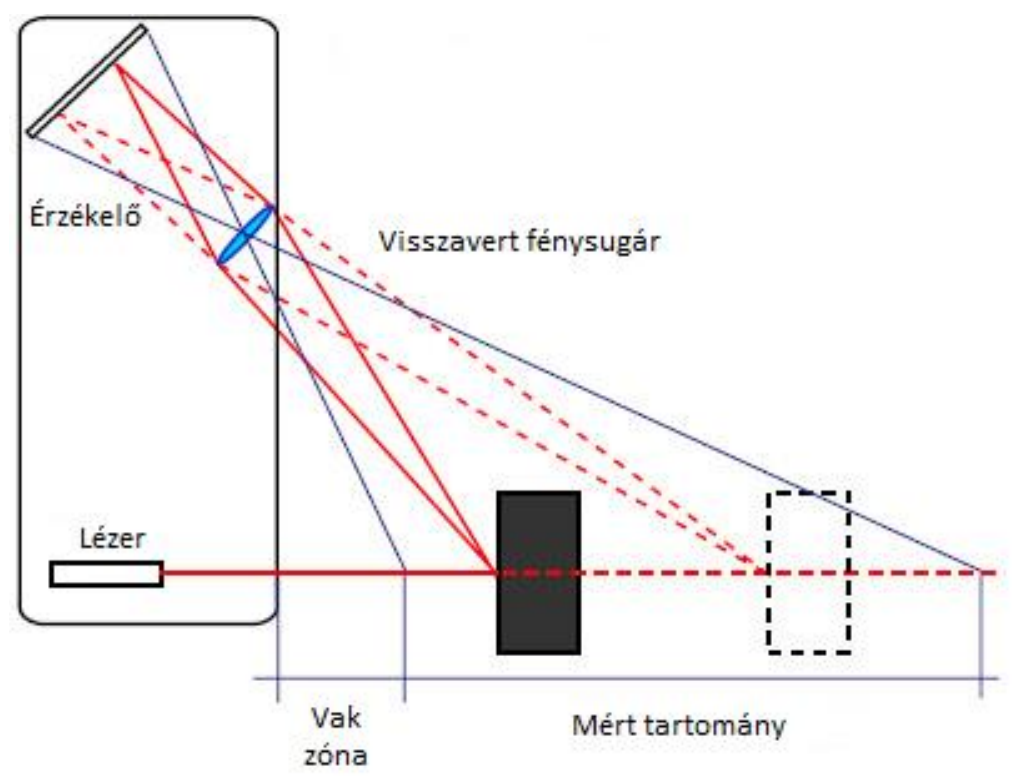

2. ábra. Háromszögeléses lézeres távolságmérö

\section{A tervezett mérőeszköz}

A digitális kamerák és a képfeldolgozás folyamatos fejlődése lehetővé teszi alkalmazásukat akár érintésmentes rezgésmérésre is. A képérzékelők felbontása megfelelő a célra, képpont méretük általában néhány mikrométer, egy megfelelő optikával ez elégséges pontosságot eredményezhet. A mintavételezési sebesség (képsebesség, vagy képfrekvencia) jelenthet problémát, mivel egy nagyfelbontású képérzékelő nagy mennyiségű adatot jelent, amit nagy sebességgel továbbítani és feldolgozni nem egyszerü feladat. Itt jönnek képbe a vonalkamerák és képérzékelő elemük a vonal CCD, vagy CMOS szenzor (3. ábra). Ez egy olyan képérzékelö, amely hasonlít a digitális kamerákban alkalmazott egységhez, azonban csak egyetlen képpont-érzékelö sort tartalmaz. Céljainknak ez megfelel, mivel csak egy irány mentén akarjuk az elmozdulást vizsgálni. Mivel mintavételenként csak egyetlen képpont-sort kell továbbítani és feldolgozni, a hagyományos (area scan) egységekhez képest akár több ezerszeres képsebesség érhető el.

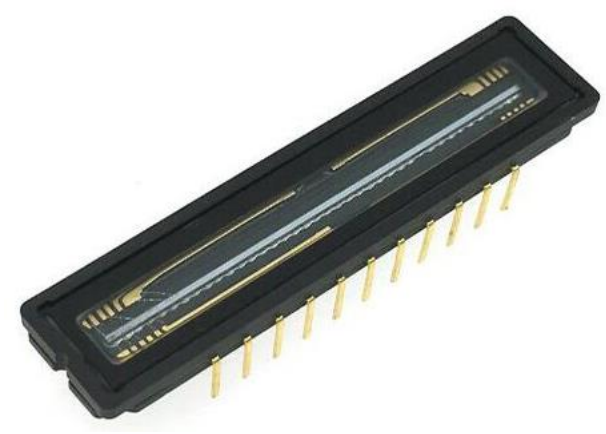

3. ábra. Toshiba TCD1209 vonal CCD képszenzor 
A vonalkamerás mérés hátránya, hogy szükség van hozzá egy számítógépre és egy képfeldolgozó szoftverre. Kutatásom célja az volt, hogy egy önállóan müködőképes eszközt tervezzek, amely önmagában képes a mérés és mérésadatgyüjtés elvégzésére. Ehhez tulajdonképpen egy „okos” vonalkamerát terveztem, amely a képérzékelő mellett tartalmazza a szükséges elektronikát és a feldolgozó számítógépet is. A CCD egység müködtetéséhez nagyon precíz időzítés szükséges, a szükséges órajeleket 10 ns pontossággal kell elöállítani pontosan szinkronizálva. Erre a célra egy Xilinx Spartan 3E FPGA áramkört használtam fel, mivel ennek segítségével megvalósítható a pontos időzítés, valamint párhuzamos múködéséből adódóan alkalmas a képszenzorról kapott adatok valósidejü feldolgozására is [3].

A mérési módszer lényege, hogy a mérendő tárgy felületére két vonalat kell festeni, melyek egymástól 10 milliméterre vannak, vastagságuk kb. $1 \mathrm{~mm}$ és merőlegesek a mérendő rezgés irányára. Ezt a jelzést keresi meg minden képen az FPGA-ban futó képfeldolgozó rendszer, a két vonal távolsága szolgál etalonként a valós méret számításához. A müködést szemlélteti a 4. ábra: az optika előtti szürke terület a látómező, a vörös háromszög a megvilágításként szolgáló vonallézert szemlélteti, az optikával szemben a fehér felület a céltárgy rajta a két függőleges jelzéssel.

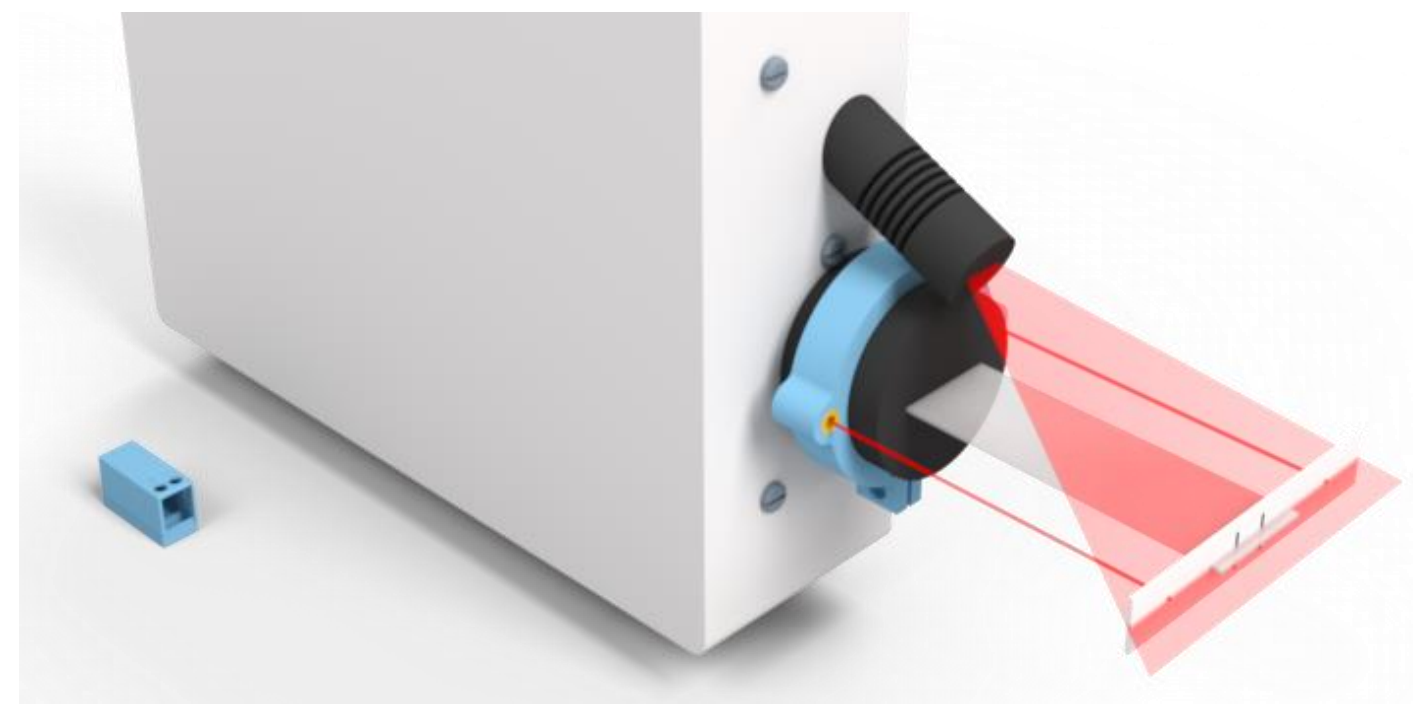

4. ábra. A berendezés müködése

A berendezés müködőképességét és pontosságát ellenőriztem más rezgésmérő eszközökkel, a mintavételezési frekvencia jelenleg $2377 \mathrm{~Hz}$, a felbontás $15 \mu \mathrm{m}$. A feldolgozó rendszer része egy FFT egység, amely 2048 feldolgozott kép (vagyis 2048 pozíciómérés) után 2048 vonalas spektrumot számít gyors Fourier-transzformáció segítségével. Ez jelenleg azt jelenti, hogy a spektrum kb. 0,9 másodpercenként frissül, ami a mintavételezési frekvenciából, illetve az FFT számításhoz szükséges időből (130 $\mu$ s) adódik, ez a későbbiekben töredékére csökkenthető. A mintavételezési frekvencia növelhető, jelenleg a viszonylag elavult CCD szenzor sebessége korlátozza.

Kutatásom jelenlegi célpontja az adatok átvitele más eszközre, számítógépre, tabletre, vagy akár okostelefonra megjelenítés, elemzés és tárolás céljából. Erre a célra beépítésre került egy Wifi modullal rendelkező mikrovezérlő, amely folyamatosan olvassa az adatokat az FPGA egységtől SPI protokollon keresztül és Wifi kapcsolaton továbbítja. Az adatok továbbításához szükség volt egy olyan adatátviteli protokollra, amely elég egyszerü ahhoz, hogy egy mikrovezérlőn megvalósítható legyen, de biztosítsa az adatok sértetlen átvitelét. Erre a célra az MQTT (Message Queuing Telemetry Transport) protokollt választottam, mivel jól dokumentált [2], rendelkezésre áll mikrovezérlős megva- 
lósítása és publisher/subscriber felépítése megfelel akár több eszközzel történő egyszerủ kommunikációhoz, valamint direkt kis sávszélességgel és számítási teljesítménnyel rendelkező eszközökhöz fejlesztették ki. A megjelenítést egy tetszőleges, a mérőeszközzel azonos Wifi hálózatra csatlakozó számítógép végezheti, jelenleg egy egyszerü Java nyelven írt program látja el ezt a feladatot. Két diagramot rajzol és frissít folyamatosan, melyek az 5. ábrán láthatók, a felső diagram mutatja az elmozdulás értékét, az alsó pedig a rezgés frekvenciaspektrumát.

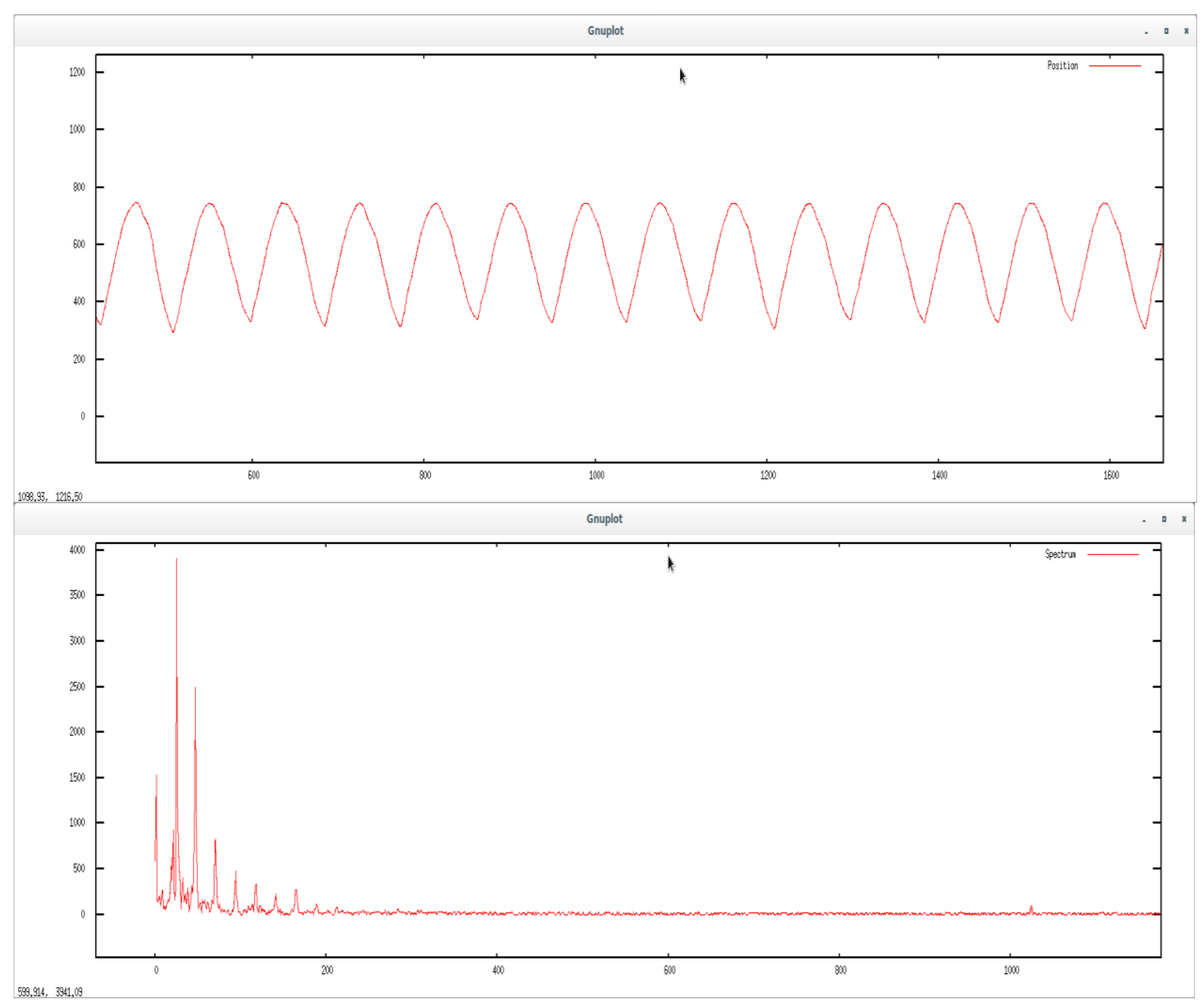

5. ábra. A mért adatok megjelenitése

\section{4. Összefoglalás}

A cikkben bemutattam az optikai elven történő érintésmentes rezgésmérés lehetséges módszereit, valamint azok alapján az általam tervezett mérőeszközt. A tervezés legfőbb szempontjai az egyszerü felépítés, önálló müködés és az alacsony előállítási költség volt. Röviden ismertettem az eszköz müködésének elvét, használatának módját. A tervezés jelenlegi fázisában az adatok megjelenítése, elemzési lehetőségei az aktuális megoldandó feladat. Későbbi továbbfejlesztési lehetőségként megemlíten- 
dő a kezelőfelület fejlesztése a minél kényelmesebb használat elősegítésére, valamint a mérési paraméterek - mint mintavételi sebesség, felbontás - javítása.

\section{Köszönetnyilvánítás}

A cikkben ismertetett kutató munka az EFOP-3.6.1-16-2016-00011 jelü „Fiatalodó és Megújuló Egyetem - Innovatív Tudásváros - a Miskolci Egyetem intelligens szakosodást szolgáló intézményi fejlesztése” projekt részeként - a Széchenyi 2020 keretében - az Európai Unió támogatásával, az Európai Szociális Alap társfinanszírozásával valósul meg.

\section{Irodalom}

[1] Ganssle, J.: A designer's guide to MEMS sensors, DigiKey Article Library, Convergence Promotions LLC, 2012.

[2] Banks, A., Gupta, R.: MQTT Version 3.1.1 Plus Errata 01, OASIS Standard Incorporating Approved Errata, 2015.

[3] Lénárt, J.: Optical Vibration Analysis with Linear CCD Sensor and Reconfigurable Hardware, Procedia Engineering 96, pp. 268-272, 2014. https://doi.org/10.1016/j.proeng.2014.12.153 